\title{
INVESTIGATING GENE INTROGRESSION FROM RAPE TO WILD TURNIP
}

\author{
T.E JENKINS ${ }^{1}$, A.J. CONNER ${ }^{1,2}$ and C.M. FRAMPTON ${ }^{3}$
}

\author{
${ }^{1}$ Soil,Plant and Ecological Sciences Division, PO Box 84, Lincoln University, \\ New Zealand
}

${ }^{2}$ Crop \& Food Research, Private Bag 4704, Christchurch, New Zealand ${ }^{3}$ Applied Management and Computing Division, PO Box 84,Lincoln University, New Zealand

Corresponding author: jenkit@lincoln.ac.nz

\begin{abstract}
Gene introgression from crops to weedy relatives has become an important issue with the development and release of transgenic crops. This study investigates hybridization between rape and a New Zealand population of wild turnip (Makarewa, Southland). The rape used was a rapid cycling non-transgenic line, homozygous for a single dominant mutation conferring resistance to the herbicide chlorsulfuron. Seed from wild turnip plants were harvested following hand pollination in a greenhouse and after natural pollination in field trials that were conducted at two ratios of rape:wild turnip, 1:1 and 1: 400. Interspecific hybrids were identified in the progeny populations by in vitro screening of seedlings for resistance to chlorsulfuron. Their hybrid status was confirmed by DNA content using flow cytometry. As expected, hand pollinations produced $100 \%$ hybrid progeny, illustrating a high potential for interspecific hybridization between rape and wild turnip. In contrast, hybrids were very rare under natural field conditions.

Keywords: rape, wild turnip, chlorsulfuron, gene introgression, herbicide resistance.
\end{abstract}

\section{INTRODUCTION}

The introduction of transgenic crops with novel traits, such as herbicide resistance, is considered to pose three major risks: 1) perceived danger to humans or other livestock feeding on the plants (Crawley et al. 1993), 2) the crops becoming persistent weeds (Conner 1997) and 3) the introgression of the novel trait to related weed species (Dale \& Scheffler 1993). Wild turnip (Brassica rapa ssp. sylvestris) is a potential risk for accidental escape of transgenes in New Zealand because it is one of the few naturalised or native species in this country that is closely related to a crop, and rape (B. napus) is an important target for transgenic technology.

The natural interspecific hybridization of rape and wild turnip is controversial (Rieger et al. 1999). Up to 95\% hybrid seed has been found on wild turnip plants in Denmark (Mikkelsen et al. 1996) and 10-88\% in New Zealand (Palmer 1962). In contrast, others have found hybridization of less than $1 \%$ in Canada (Bing et al. 1991) and England (Wilkinson et al. 2000). In this study a chlorsulfuron-resistant mutant rape was used to model the potential for gene introgression from rape to a New Zealand population of wild turnip.

\section{Plant Material}

\section{MATERIALS AND METHODS}

Wild turnip seeds were sourced from Pomona Road, Makarewa, Southland. The rape used is a non-transgenic line, homozygous for a single dominant mutation conferring resistance to the herbicide chlorsulfuron (Conner et al. 1994). 


\section{Hand Pollination}

Six plants from the Southland population and six rape plants were grown to flowering in twelve 5 litre pots of standard potting mix (80\% composted bark, $20 \%$ sand WAP 5, with Osmocote Plus 15-4.8-10.8, 3-4 months release at $2 \mathrm{~kg} / \mathrm{m}^{3}$ and Dolomite lime at $2 \mathrm{~kg} / \mathrm{m}^{3}$ ) in a glasshouse. Two individual flowers in the turnip raceme were opened while at the yellow bud stage, emasculated and pollinated with mature rape pollen for each of the six rape plants, resulting in 12 pollinations. The flowers were capped with aluminium foil and left for a week, when the cap was removed and the silique left to ripen for later harvest of seed.

\section{Field Pollination}

About 800 Southland wild turnip seeds were sown at the Field Service Center, Lincoln University in a $5 \mathrm{~m} \times 2 \mathrm{~m}$ plot. When the wild turnips began to flower, two already-flowering rape plants in pots were placed in the wild turnip patch so that wild turnip plants were never more than $1.5 \mathrm{~m}$ from a rape plant. The plants were left to pollinate naturally. Seed from ten randomly selected wild turnip plants was harvested and screened for hybrid progeny (see below).

For the 1:1 study, rape and turnip seeds were sown in the glasshouse and transplanted when at the three true leaf stage into the field at the Field Service Center approximately $50 \mathrm{~m}$ from the other trial in a row of 40 alternating plants, amongst 5 other wild turnip populations.

The next spring many turnip volunteers germinated on the trial site. The population density was calculated, then the plants were sprayed with Glean (20 g ai (chlorsulfuron)/ha) and survivors recorded.

\section{Hybrid Screening}

Seeds were surface sterilised by immersion in $1 \%$ sodium hypochlorite (plus a drop of Tween 20) for $10 \mathrm{~min}$, followed by 3 rinses with sterile water. Seeds were sown onto the surface of nutrient medium consisting of half strength MS salts (Murashige \& Skoog 1962) at pH 5.8 solidified with $0.8 \%$ (w/v) Gibco bacteriological agar. This medium was autoclaved for $15 \mathrm{~min}$ at $103 \mathrm{kPa}$, then filter-sterilised chlorsulfuron was added to a final concentration of $10 \mu \mathrm{g} / \mathrm{litre}$, just prior to dispensing $50 \mathrm{ml}$ into presterilised plastic pottles. Seeds sown in each pottle were germinated at $24-26^{\circ} \mathrm{C}$ under light from cool white fluorescent lamps $\left(80-100 \mu \mathrm{mol} / \mathrm{m}^{2} / \mathrm{sec}, 16 \mathrm{~h}\right.$ photoperiod). Seedling root extension into the media is negligible if there is no resistance to the herbicide, and may be up to $5 \mathrm{~cm}$ after a week if resistance is present (Conner et al. 1994). Resistance only exists in hybrid progeny.

\section{Flow Cytometry}

Some of the hybrids resulting from the hand pollination trial and survivors from the field spraying were grown on and subjected to flow cytometry to confirm their hybrid status. Three hybrid progeny were sampled (two plants produced only two hybrids) from each wild turnip plant used for hand pollinations. Flow cytometry was performed as described by Morgan et al. (1995). In brief, nuclei were isolated following the chopping of leaves in Galbraith's buffer, treated with RNAase (DNAase-free) and stained with $50 \mu \mathrm{g} / \mathrm{ml}$ propidium iodide. They were then analysed on an Epics Profile II flow cytometer (Coulter Electronics Inc.), fitted with an argon laser ( $488 \mathrm{~nm})$ that operated at $15 \mathrm{~mW}$. Parsley (4.72 pg DNA/2C nucleus) was used as an internal standard with each sample after calibration against barley (11.12 pg DNA/2C nucleus) and pea (9.73 pg DNA/2C nucleus).

\section{Statistical analysis}

Hybridization percentages were compared between the field trials using ANOVA, with individual plants used as replicates.

\section{RESULTS AND DISCUSSION}

Just over half of the hand pollinations resulted in the formation of a silique (Table 1). Within each silique there was an average of 9.5 seeds, which is substantially lower than that expected from normal pollination (over 30 seeds per silique). Of these seeds, all those that successfully germinated were hybrids, illustrating the high potential for interspecific hybridization from rape to wild turnip. 
TABLE 1: Incidence of interspecific hybridization between Southland wild turnip and chlorsulfuron-resistant rape following hand pollination.

\begin{tabular}{lcccccc}
\hline $\begin{array}{l}\text { Plant } \\
\text { number }\end{array}$ & $\begin{array}{c}\text { Number of } \\
\text { pollinations } \\
\text { attempted }\end{array}$ & $\begin{array}{c}\text { Number of } \\
\text { siliques } \\
\text { formed }\end{array}$ & $\begin{array}{c}\text { Number of } \\
\text { seeds } \\
\text { harvested }\end{array}$ & $\begin{array}{c}\text { Number of } \\
\text { seeds } \\
\text { germinated }\end{array}$ & $\begin{array}{c}\text { Number of } \\
\text { hybrids }\end{array}$ & $\begin{array}{c}\% \text { Hybrids } \\
\text { of seeds } \\
\text { germinated }\end{array}$ \\
\hline 1 & 12 & 7 & 52 & 37 & 37 & 100 \\
2 & 12 & 7 & 53 & 48 & 48 & 100 \\
3 & 12 & 9 & 90 & 74 & 74 & 100 \\
4 & 12 & 7 & 66 & 57 & 57 & 100 \\
5 & 12 & 3 & 70 & 68 & 68 & 100 \\
6 & 12 & 8 & 57 & 49 & 49 & 100 \\
Total & 72 & 41 & 388 & 333 & 333 & 100 \\
\hline
\end{tabular}

${ }^{1}$ Remaining seed either failed to germinate due to dormancy or inviability, or pregerminated within the developing silique.

The mean DNA content of the turnip nuclei was $1.175 \mathrm{pg} / 2 \mathrm{C}(\mathrm{SD}=0.02)$ and rape was $2.534 \mathrm{pg} / 2 \mathrm{C}(\mathrm{SD}=0.06)$. This difference reflects the diploid and tetraploid status of the two species. The sixteen hybrids analysed for their DNA content had a mean of $1.877 \mathrm{pg} / 2 \mathrm{C}$ nucleus and a range of $1.83-1.90 \mathrm{pg} / 2 \mathrm{C}$ nucleus, a DNA content consistent with the expected triploid status of interspecific hybrids between wild turnip and rape. These results confirmed the accuracy/validity of the screening method used.

Despite the high potential for interspecific hybridization between rape to wild turnip in hand pollinations, hybrids were very rare under natural field conditions (Table 2). Individual plants in the field trial were not significantly different so pooled data from the 10 plants sampled in each trial is presented. There was a highly significant difference $(\mathrm{P}<0.001)$ between the hand-pollinated trial and the trials conducted in the field. There was no $(\mathrm{P}>0.05)$ difference in the frequency of hybrids between the different field trials, either with respect to seasons or species ratio.

TABLE 2: Interspecific hybridization between Southland wild turnip plants and chlorsulfuron-resistant rape in the field at two different ratios of rape:wild turnip

\begin{tabular}{lcccc}
\hline Trial & $\begin{array}{c}\text { Number of } \\
\text { seeds harvested }\end{array}$ & $\begin{array}{c}\text { Number of } \\
\text { seeds screened }\end{array}$ & $\begin{array}{c}\text { Number of } \\
\text { hybrids found }\end{array}$ & \% Hybrids \\
\hline $1: 1(1998)$ & 103253 & 2055 & 20 & 0.97 \\
$400: 1(1998)$ & 51486 & 1739 & 37 & 2.13 \\
400:1 (1999) & 9944 & 9944 & 6 & 0.06 \\
Total & 164683 & 13738 & 63 & 0.46 \\
\hline
\end{tabular}

It is interesting that increasing the ratios of rape to wild turnip (from 1:400 to 1:1) did not significantly change the percentage of hybrids produced, which is different from the results reported by Mikkelsen et al. (1996), who found the ratio changed the percentage of hybrids formed. The low percentages of hybrids reported is similar to the results reported by Wilkinson et al. (2000) and Bing et al. (1991).

Many wild turnip volunteers appeared at the field trial sites in the spring following each trial. When these were sprayed with chlorsulfuron only a single resistant plant was observed among the estimated total of 10870 volunteers. The putative field hybrid had $1.86 \mathrm{pg}$ DNA/2C nucleus, confirming that it was a triploid and therefore a hybrid. It did not set any seed although pollen donors were available. This reinforces the low frequency of interspecific hybridization between wild turnip and rape under field conditions. 


\section{REFERENCES}

Bing, D.J.; Downey, R.K.; Rakow, G.F.W. 1991: Potential of gene transfer among oilseed brassica and their weedy relatives. Proc. GCTRC 8th Int. Rape. Cong., 9-11 July 1991, Saskatoon, Saskatchewan. Pp.1022-1027.

Conner, A.J. 1997: Genetically engineered crops, Environmental and food safety issues. RSNZ Miscellaneous series 39, Wellington, New Zealand.

Conner, A.J.; Abernethy, D.J.; Dastgheib, F.; Field, R.J. 1994: Brassica napus mutants with increased chlorsulfuron resistance. Proc. 47th N.Z. Plant Prot. Conf.:173177.

Crawley, M.J.; Haus, R.S.; Rees, M.; Kolin, D.; Buxton, J. 1993: Ecology of transgenic oilseed rape in natural habitats. Nature 363: 620-623.

Dale, P.J.; Scheffler, J.A. 1993: Release of transgenic oilseed crops. In:Murphy, D.J.ed. Designer Oilseed Crops. VCH Verlagsgesellschaft mbH, Weinheim. Pp. 283-296.

Mikkelsen, T.R.; Jensen, J.; Jørgensen, R.B. 1996: Inheritance of oilseed rape Brassica napus RAPD markers in a backcross progeny with Brassica campestris. Theor. Appl. Genet. 92: 492-497.

Morgan, E.R.; Burge, G.K.; Seelye, J.F.; Grant, J.E.; Hopping, M.E. 1995: Interspecific hybridization between Limonium perigrinum Bergius and Limonium purpuratum L. Euphytica 83: 215-224.

Murashige, T.; Skoog, F. 1962: A revised medium for rapid growth and bioassays with tobacco tissue cultures. Physiol. Plant. 15: 473-497.

Palmer, T.P. 1962: Population structure, breeding system, inter-specific hybridization and alloploidy. Heredity 17: 278-283.

Rieger, M.A.; Preston, C.; Powles, S.B. 1999: Risks of gene flow from transgenic herbicide-resistant canola (Brassica napus) to weedy relatives in southern Australian cropping systems. Aus. J. Agric. Res. 50: 115-128.

Wilkinson, M.J.; Davenport, I.J.; Charters, Y.M.; Jones, A.E.; Allainguillaume, J.; Butler, H.T.; Mason, D.C.; Raybould, A.F. 2000: A direct regional scale estimate of transgene movement from genetically modified oilseed rape to its wild progenitors. Mol. Ecol. 9: 983-991. 